\title{
DETEKSI DINI DAN PERAWATAN KESEHATAN PADA PERMASALAHAN KESEHATAN KELOMPOK KHUSUS DI RW O6 KELURAHAN KARAH KECAMATAN JAMBANGAN
}

\author{
Nur Ainiyah \\ Prodi S1 Keperawatan, Fakultas Keperawatan dan Kebidanan, Universitas Nahdlatul Ulama Surabaya, \\ ainiyahannuri@unusa.ac.id
}

Ima Nadatien

Prodi S1 Keperawatan, Fakultas Keperawatan dan Kebidanan, Universitas Nahdlatul Ulama Surabaya

\section{Umi Hanik}

Prodi S1 Keperawatan, Fakultas Keperawatan dan Kebidanan, Universitas Nahdlatul Ulama Surabaya

\begin{abstract}
Abstrak
Kelompok khusus merupakan sekelompok masyarakat atau individu yang memerlukan bantuan dikarenakan ketidakmampuan dan ketidaktahuan dalam memelihara kesehatan dan perawatan dirinya sendiri. Berdasarkan hasil observasi di RW 06 Karah banyak kelompok khusus yang menderita Hipertensi 12 orang ( 9 orang tidak mengkonsumsi obat hipertensinya secara rutin dan 3 orang sering mengalami kekambuhan), Diabetes Mellitus 15 orang ( 1 orang mempunyai luka gangren, 5 orang tidak mengkonsumsi obat antidiabetik), sedangkan dari hasil laporan posyandu balita diketahui terjadi peningkatan kejadian ISPA tiap bulannya. Kegiatan pengabdian pada masyarakat ini dilakukan untuk meningkatkan pengetahuan dan penanganan tentang masalah kesehatan yang terjadi pada kelompok khusus dan demonstrasi intervensi keperawatannya. Metode yang dilakukan adalah dengan memberikan edukasi kesehatan tentang Hipertensi, Diabetes Mellitus dan ISPA serta memberikan demonstrasi mengenai fisioterapi, cuci tangan, gosok gigi dan pelaksanaan senam diabetes serta senam lansia. Hasil luaran dari kegiatan pengabdian kepada masyarakat ini adalah peserta (kelompok khusus) senang dan antusias dengan kegiatan ini. Jumlah peserta yang hadir dalam edukasi kesehatan ISPA dan cuci tangan ini 20 balita dengan orangtuanya, ada 18 orang mengikuti senam lansia, sedangkan pemeriksaan kesehatan diikuti 40 orang. Hasil pemeriksaan tekanan darah menunjukkan adanya tekanan darah optimal sejumlah 4 orang $(10 \%)$, normal 4 orang $(10 \%)$, normal tinggi 11 orang $(27,55)$, hipertensi derajat 1: 16 orang $(40 \%)$ serta hipertensi derajat 2: 5 orang $(12,5 \%)$, adanya peningkatan pengetahuan dan ketrampilan tentang fisioterapi dada, gosok gigi, cuci tangan serta senam. Pengabdian masyarakat diharapkan masyarakat dapat melakukan pencegahan dan penatalaksanaan pada dirinya dan anggota keluarganya ketika menderita Diabetes Mellitus, Hipertensi dan ISPA.
\end{abstract}

Kata Kunci: deteksi dini, perawatan, kelompok khusus

\begin{abstract}
Special groups are groups of people or individuals who need help due to their inability and ignorance in maintaining their own health and care. Based on observations in RW 6 Karah, many special groups suffered from hypertension 12 people (9 people did not take hypertension drugs regularly and 3 people often experienced recurrence), Diabetes Mellitus 15 people (1 person had gangrenous injuries, 5 people did not take antidiabetic drugs), while the results of the Posyandu toddler's report are known to increase the incidence of ARI each month. Community service activities are carried out to improve knowledge and handling of health problems that occur in special groups and demonstration of nursing interventions. The method used is to provide health education about Hypertension, Diabetes Mellitus and ARI and provide demonstrations about physiotherapy, hand washing, brushing and implementing diabetes exercises and elderly gymnastics. The outcome of this community service activity was the participants (special groups) were happy and enthusiastic about this activity. The number of participants present in ISPA and hand washing health education was 20 toddlers with their parents, there were 18 people participating in elderly gymnastics, while health checks were attended by 40 people. The results of blood pressure examination showed an optimal blood pressure of 4 people (10\%), normal 4 people (10\%), normal high 11 people (27.55), hypertension degree 1: 16 people (40\%) and hypertension degree 2: 5 people (12.5\%),
\end{abstract}


there is an increase in knowledge and skills about chest physiotherapy, brushing teeth, hand washing and gymnastics. Community service is expected that the community can prevent and manage themselves and their family members when suffering from diabetes mellitus, hypertension and ARI.

Keywords: detection, care, a special group

\section{PENDAHULUAN}

Kelompok khusus merupakan sekelompok masyarakat atau individu yang mempunyai keadaan fisik, mental, social, budaya dan ekonomi perlu mendapatkan bantuan, bimbingan dan pelayanan kesehatan dan asuhan keperawatan karena ketidakmampuan dan ketidaktahuan mereka dalam memelihara kesehatan dan perawatan dirinya sendiri.

Berdasarkan hasil observasi di RW 06 Karah banyak kelompok khusus yang menderita Hipertensi 12 orang (9 orang tidak mengkonsumsi obat hipertensinya secara rutin dan 3 orang sering mengalami kekambuhan), Diabetes Mellitus 15 orang (1 orang mempunyai luka gangren, 5 orang tidak mengkonsumsi obat antidiabetik). Hasil wawancara dengan masyarakat RW 6 menunjukkan bahwa banyak warga yang tidak mengetahui tanda tanda dan komplikasi pada Hipertensi dan Diabetes Mellitus, sedangkan dari hasil observasi diketahui anak - anak yang tinggal di RW 06 ini banyak yang jajan sembarangan dan hal ini dibiarkan oleh orang tuanya, dan dari laporan posyandu balita diketahui terjadi peningkatan kejadian ISPA tiap bulannya.
Kelompok khusus yang dimaksudkan dalam pengabdian masayarakat ini adalah usia lansia serta balita. Kelompok khusus ini mudah menderita penyakit degenerative (seperti Hipertensi dan Diabetes Mellitus) dan ISPA. Hal ini disebabkan karena adanya beberapa faktor antara lain yaitu anatomis pernafasan yang lebih pendek daripada balita dibandingkan pada orang dewasa sehingga anak balita lebih mudah terkena penyakit ISPA. Adapun unsur penyebab terjadinya penyakit pada kelompok lansia antara lain karena gangguan degeneratif dapat disebabkan karena elastisitas pembuluh darah yang menurun serta anatomi organ jantung pada lansia yang berbeda dengan usia yang lebih muda.

Dalam meminimalkan kejadian ISPA dan penyakit degeneratif, perlu adanya koordinasi dan penanganan yang cepat, tepat, efektif, efisien, salah satunya dengan meningkatkan pengetahuan tentang tanda dan gejala penyakit, pencegahan dan penatalaksanaan perawatannya pada lansia dan balita.

GAMBARAN UMUM MASYARAKAT SASARAN

RW 06 merupakan salah satu RW yang terletak di Kelurahan Karah Kecamatan 
Jambangan Surabaya didapatkan bahwa jumlah populasi warga RW 06 seluruhnya sebanyak 381 KK dengan warga tetap sebanyak 1169 jiwa. Dari hasil observasi pada 100 KK diketahui bahwa kondisi kesehatan dalam 6 bulan terakhir.

Tabel 1. Distribusi frekuensi kondisi kesehatan umum 6 bulan terakhir pada warga di RW 06 Kelurahan Wonokromo Surabaya.

\begin{tabular}{|c|c|c|c|}
\hline No & Kondisi Umum & Jumlah & \% \\
\hline 1 & ISPA & 62 & 62 \\
\hline 2 & DBD & 3 & 3 \\
\hline 3 & Gastroenteritis & 0 & 0 \\
\hline 4 & Typoid & 2 & 2 \\
\hline 5 & Asma & 4 & 4 \\
\hline 6 & $\begin{array}{c}\text { Infeksi menular } \\
\text { seksual }\end{array}$ & 3 & 3 \\
\hline 7 & DM & 15 & 15 \\
\hline 8 & HT & 12 & 12 \\
\hline & Jumlah & 100 & 100 \\
\hline
\end{tabular}

\section{METODE}

Pengabdian masyarakat ini dilakukan dengan tiga tahap yaitu pra kegiatan (survey lokasi dan analisis situasi), pelaksanaan kegiatan yaitu dengan melakukan pemeriksaan tekanan darah dan glukosa darah, edukasi kesehatan tentang Hipertensi, Diabetes Mellitus, ISPA serta demonstrasi cuci tangan, gosok gigi, fisioterapi dada serta senam lansia dan senam diabetes mellitus. Ketiga yaitu evaluasi, evaluasi dilakukan pre dan post edukasi kesehatan. Populasi dalam pengabdian masyarakat ini adalah masyarakat yang tinggal di RW 06 Kelurahan Karah Kecamatan Jambangan
Surabaya. Sampel dalam pengabdian masyarakat ini adalah kelompok khusus yaitu lansia dan balita atau anak usia sekolah. Tehnik pengumpulan yaitu dengan mendata di PAUD yang ada di Balai RW 06 tersebut serta mendatangi posyandu lansia. Untuk pengabdian masyarakat ini menggunakan tensimeter, glukosastik, puzzle, phantom gigi, handscrub.

\section{HASIL DAN PEMBAHASAN}

Pemeriksaan Kesehatan dilakukkan pada tanggal 24 Januari 2018 sekaligus dengan edukasi kesehatan Diabetes Mellitus dan Hipertensi, dihadiri 40 orang (terlampir). Dari hasil pemeriksaan tekanan darah yang menunjukkan tekanan darah optimal sejumlah 4 orang (10\%), normal 4 orang (10\%), normal tinggi 11 orang $(27,55)$, hipertensi derajat 116 orang $(40 \%)$ serta hipertensi derajat 2 sejumlah 5 orang $(12,5 \%)$.

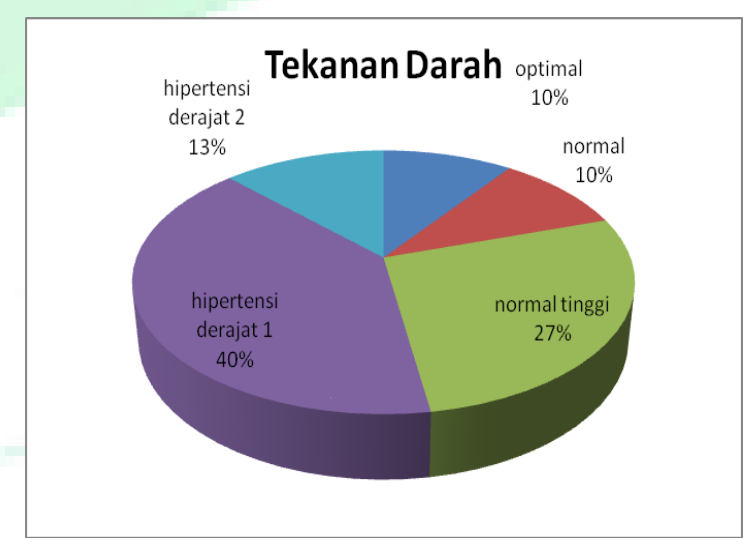

Gambar 1 Hasil Pemeriksaan Tekanan Darah Di RW 06 Karah Jambangan Surabaya.

Sedangkan dari Pemeriksaan Gula Darah didapatakan 22 orang dengan gula 
darah normal dan abnormal sejumlah 18 orang

(Gambar 5.2)

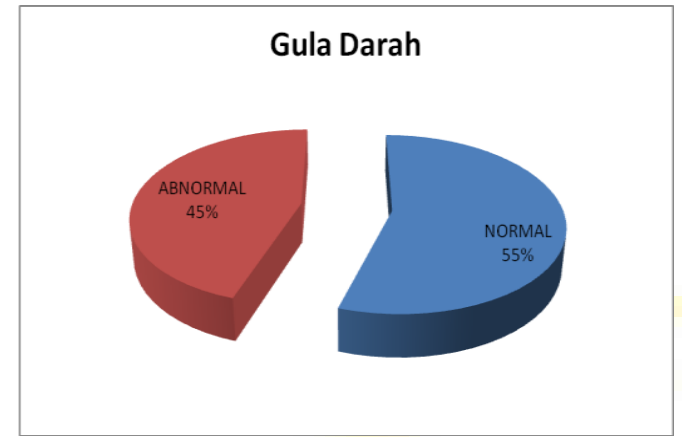

Gambar 2 Hasil Pemeriksaan Gula Darah di RW 06 Karah Jambangan Surabaya.

Dalam pengabdian masyarakat ini juga dilakukan demonstrasi tentang cuci tangan dilakukan bersamaan dengan fisioterapi dada sekaligus edukasi kesehatan ISPA dilakukan pada balita dan ibu balita tanggal 25 Juni 2018 di pos PAUD RW 06 Kelurahan karah. Demonstrasi ini dilakukan secara langsung, yaitu anak balita dan orang tuanya menirukan pemateri ketika mengajarkan cara cuci tangan yang benar. Sedangkan demonstrasi dilakukan bersama balita dan anak usia sekolah di depan Balai RW 06 dengan menggunakan metode puzzle dan demonstarsi langsung pada phantom gigi. Sedangkan untuk demonstrasi senam lansia dilakukan bersama sama di halaman sekolah SMK Kartika pada tanggal 25 Juni 2018 jam 07.00 dan Balai RW 06 tanggl 24 Juni 2018 pada warga masyarakat yang menderita Diabetes Mellitus dan non diabetes.

Luaran yang dicapai dari kegiatan pengabdian masyarakat ini adalah peningkatan kualitas kesehatan di adalah pemeriksaan kesehatan gula darah dan tekanan darah sebagai upaya deteksi terhadap penyakit yang lebih serius, peningkatan pengetahuan responden tentang bahaya penyakit Diabetes Mellitus, Hipertensi dan ISPA, kemampuan kelompok khusus dalam melakukan senam diabetes mellitus dan senam lansia serta fisioterapi dada, gosok gigi dan cuci tangan. Publikasi ilmiah di jurnal juga merupakan luaran yang dicapai dalam pengabdian masyarakat ini.

\section{KESIMPULAN}

Pengabdian Masyarakat ini bertujuan untuk meningkatkan kesehatan responden, meningkatkan pengetahuan responden tentang bahaya Diabetes Mellitus, Hipertensi dan ISPA.

Oleh karena itu diperlukan peran aktif kader dan tenaga kesehatan dalam pemeriksaan gula darah dan tekanan darah sehingga terjadi peningkatan derajat kesehatan masyarakat terutama kelompok khusus, perlu adanya pelatihan-pelatihan penunjang bagi kelompok khusus ataupun keluarganya penting untuk diberikan untuk pencegahan dan penatalaksanaan penyakit Diabetes dan Hipertensi serta ISPA, peningkatan peran aktif masyarakat terutama kader posyandu lansia dan balita. 


\section{REFERENSI}

Azizah, Lilik Ma'rifatul. (2011). Keperawatan Lanjut Usia. Edisi 1. Yogyakarta : Graha Ilmu

Badan POM. (2015). Materi Edukasi tentang Peduli Obat dan Pangan Aman.

Gerakan nasional Peduli Obat dan Pangan Aman : Badan POM
Infodatin Pusat Data dan Informasi Kementrian Kesehatan RI. (2016). Situasi Lanjut Usia (Lansia) di Indonesia : 29 Mei Hari lanjut Usia. Kementrian Kesehatan RI

Kementrian Kesehatan RI. (2013). Buletin Jendela Data dan Informasi Kesehatan. Semester I. Diakses dari website www.depkes.go.id pada tanggal 10 Mei 2018 pukul 13.00 WIB 